\title{
Evaluation of Tribological Properties of Hard Coatings Obtained on Steel C45 by Electro-Spark Alloying
}

\author{
Vladimir Kukareko ${ }^{1}$, Vasile Agafii ${ }^{2,}{ }^{*}$, Valentin Mihailov ${ }^{2}$, Aleksandr Grigorchic $^{1}$, Natalia Kazak ${ }^{2}$ \\ ${ }^{1}$ Center for Structural Research and Tribo-Mechanical Testing of Materials and Mechanical Engineering \\ Products, United Institute of Mechanical Engineering of the NAS of Belarus, Minsk, Belarus \\ ${ }^{2}$ Laboratory of Electrophysical and Electrochemical Methods of Materials Treatment "Boris \\ Lazarenko", Institute of Applied Physics, Chisinau, Moldova \\ E-mail: vasile.agafii@mail.ru
}

Keywords: electro-spark alloying, coating, roughness, microhardness, wear intensity, coefficient of friction

\begin{abstract}
It was shown that under dry contact conditions, under normal load of to $2 \mathrm{MPa}$, all coatings demonstrated a significant increase in wear resistance compared to that of the substrate. However, among them, the Mo coating showed the highest wear resistance: $\sim 20$ times higher than that of the uncoated steel. That was caused not only by the Mo high microhardness and the lowest initial roughness, but also by the structure of this coating. Meanwhile, the $\mathrm{Ti}+\mathrm{SiC}$ samples displayed the highest microhardness among investigated coatings. A correlation was established between the microhardness of the coating and the friction coefficient: the larger the microhardness of the coating, the higher is the coefficient of friction. An X-ray analysis of the coatings obtained by ESA on steel with compositions $(\mathrm{Ti}+\mathrm{Al}+\mathrm{C}),(\mathrm{Ti}+\mathrm{AlN})$ and $(\mathrm{Ti}+\mathrm{SiC})$ revealed phases of titanium carbide, titanium nitride, intermetallic compound $\mathrm{AlFe}_{3}$, and small amounts of aluminum nitride, silicon dioxide and titanium dioxide. This could explain the high microhardness (from 6.8 up to $13.8 \mathrm{GPa}$ ) of the obtained coatings.
\end{abstract}

\section{Introduction}

Currently, the engineering industry is increasingly using a very large range of metals and alloys, which every year becomes more and more expensive. Therefore, the formation of surfaces with high hardness and high tribological properties with less expenditure of metals and alloys is an important task. It is known that one of the simplest methods of forming surfaces with high tribomechanical properties is the electro-spark alloying (ESA) of metals and alloys with electrodes of various materials [1-5]. In this paper, we studied the tribomechanical properties of electro-spark coatings obtained with hard alloy electrodes and materials that synthesized carbides, intermetallic compounds, oxides, and other substances on steel C45 (St. C45).

\section{Experimental}

Tribological tests of thin coating samples were carried out on an automated reciprocating tribometer equipped with a specially designed device for recording friction force. Coatings were deposited on the samples of St. C45 with dimensions of 5x8x6 mm, namely, on the face with dimensions of $5 \times 8 \mathrm{~mm}$. The tribological properties of the coatings from $\mathrm{Mo}, \mathrm{Ti}+\mathrm{Al}+$ graphite, $\mathrm{Ti}+$ $\mathrm{AlN}$, and from $\mathrm{Ti}+\mathrm{SiC}$, which were applied by ESA on an EFI-10M installation, were determined. In tests, a counterbody made of hardened steel U8 (HV $=7800-8000 \mathrm{MPa})$ with dimensions of 2x40x90 mm was used and its surface was ground with subsequent polishing on a fine abrasive paper with grit M40.

Tribological testing of coatings was carried out at a specific load of $2 \mathrm{MPa}$ under dry friction conditions. All test time consisted of 4 periods: the first 30 minutes $(2250$ cycles - sliding distance of 
$135 \mathrm{~m}$ ), the second 45 minutes (3375 cycles - the sliding distance of $202.5 \mathrm{~m}$ ), the third 75 minutes (5625 cycles - the sliding distance of $337.5 \mathrm{~m}$ ), and the fourth all for 75 minutes. The counterbody was reciprocating with an amplitude of $30 \mathrm{~mm}$. The average speed of the movement of the counterbody during the test was $0.075 \mathrm{~m} / \mathrm{s}$ or 75 cycles per minute.

Measurements of wear of prismatic samples were carried out by the gravimetric method using the analytical balance ADV-200M. The error in measuring the mass of the sample was $0.05 \mathrm{mg}$. Before weighing, the wear products were carefully removed from the surface of the samples and then the samples were washed, rubbed with alcohol and dried in a drying oven at a temperature of $100^{\circ} \mathrm{C}$. After drying, the samples were weighed on the analytical balance. Each sample was weighed at least 2-3 times.

The friction force $\mathrm{F}$ arising from the mutual displacement of the contacting surfaces was recorded using a strain gauge dynamometer. The deformation of the elastic element of the strain gauge dynamometer was converted using a standard strain amplifier into an electrical signal, which was inserted into a computer through a specially designed unit. After each minute of the test, the friction force was recorded 3000 times within 3 seconds. With the help of a special program, the values of the friction force were converted into the values of the friction coefficients. The measured values of the friction coefficients were subjected to statistical processing and the average value of $F$ was determined after each minute of testing.

The main reason for the wear of materials is the adhesion setting of the contacting surfaces, accompanied by a scuffing and seizing of friction units. Such processes are usually implemented with the functioning of friction devices under conditions of high contact pressures, friction without lubrication or with insufficient lubrication, as well as when working in the region of elevated temperatures. In this regard, to assess the resistance to contact destruction of electro-spark coatings, their tribological characteristics were measured under conditions of friction without a lubricant (dry friction).

The roughness of the samples before and after the tribological tests was determined on a Surtronic 25 profilograph. The initial microhardness of the samples coated with different materials was determined on a PMT-3 microhardness tester. The friction surface of the samples was studied with a NEOPHOT-30 optical microscope.

For a better comparison of the wear resistance of the coatings, we determined the true wear volume $\left(V_{u}\right)$ of each type of coatings in $\mathrm{mm}^{3}$ (taking into account the density of each type of coatings) and then their linear wear $(h) \mu \mathrm{m}$ was found (taking into account the surface of each type of coatings). Both the wear intensity $\left(I_{h}\right)$ of the coatings in $\mathrm{mkm} / \mathrm{m}$ for each wear period and the average wear intensity $\left(I_{\text {h aver }}\right)$ for the entire wear period were then determined.

\section{Results and Discussion}

Table 1 show the wear intensity $\left(I_{h}\right)$ of the coatings in the test periods 1-4 and the average wear intensity $I_{h}$ aver after a total test time of 225 minutes (or after a sliding distance of $1012.5 \mathrm{~m}$ ). Looking at table 1 , it can be noted that the lowest wear intensity of $0.0031 \mu \mathrm{m} / \mathrm{m}$ had the Ti+AlN coating in the second test period and highest wear intensity of $0.178 \mu \mathrm{m} / \mathrm{m}$ had the uncoated steel also in the first test period. The coating of Mo had the lowest wear intensity in the first, the third and the fourth period $-0.0143,0.0039$, and $0.0089 \mu \mathrm{m} / \mathrm{m}$, respectively. In the first test period, the wear intensity increased in the direction $\mathrm{Mo} \rightarrow \mathrm{Ti}+\mathrm{Al}+$ graphite $\rightarrow \mathrm{Ti}+\mathrm{SiC} \rightarrow \mathrm{Ti}+\mathrm{AlN} \rightarrow \mathrm{St} . \mathrm{C} 45$, in second test period $-\mathrm{Ti}+\mathrm{AlN} \rightarrow \mathrm{Mo} \rightarrow \mathrm{Ti}+\mathrm{SiC} \rightarrow \mathrm{Ti}+\mathrm{Al}+$ graphite $\rightarrow \mathrm{St} . \mathrm{C} 45$, in the third test period $-\mathrm{Mo} \rightarrow \mathrm{Ti}+$ $\mathrm{SiC} \rightarrow \mathrm{Ti}+\mathrm{Al}+$ graphite $\rightarrow \mathrm{Ti}+\mathrm{AlN} \rightarrow \mathrm{St} . \mathrm{C} 45$, and in the fourth test period $-\mathrm{Mo} \rightarrow \mathrm{Ti}+\mathrm{SiC} \rightarrow \mathrm{Ti}+$ $\mathrm{AlN} \rightarrow \mathrm{Ti}+\mathrm{Al}+$ graphite $\rightarrow \mathrm{St}$. C45. From table 1 it is clear that the lowest average wear intensity for the entire test period had the Mo coating. The average wear intensity increased in the direction $\mathrm{Mo} \rightarrow \mathrm{Ti}+\mathrm{SiC} \rightarrow \mathrm{Ti}+\mathrm{AlN} \rightarrow \mathrm{Ti}+\mathrm{Al}+$ graphite $\rightarrow \mathrm{St}$. C45. Therefore, after calculating the average wear intensity of the coatings, the highest wear resistance was rightly the Mo coating, and the $\mathrm{Ti}+$ $\mathrm{SiC}$ coating rankeds second. 
Table 1 . Wear intensity $I_{h}$ of coatings for each test period and average wear intensity $I_{h}$ aver. for all studied tribological periods.

\begin{tabular}{|c|c|c|c|c|c|c|}
\hline \multirow{2}{*}{$\begin{array}{c}\text { Order } \\
\text { number }\end{array}$} & \multirow{2}{*}{$\begin{array}{c}\text { Coating } \\
\text { material }\end{array}$} & \multicolumn{4}{|c|}{ Wear intensity $I_{h}$ of coatings for each test period, } & \multirow{2}{*}{$\begin{array}{c}\text { The average } \\
\text { wear intensity }\end{array}$} \\
\cline { 3 - 6 } & & $\begin{array}{c}\text { In the first } \\
\text { period }\end{array}$ & $\begin{array}{c}\text { In the second } \\
\text { period }\end{array}$ & $\begin{array}{c}\text { In the third } \\
\text { period }\end{array}$ & $\begin{array}{c}\text { In the fourth } \\
\text { period }\end{array}$ & Ih aver., $(\mu \mathrm{m} / \mathrm{m})$ \\
\hline 1. & $\begin{array}{c}\text { St. C45 } \\
\text { uncoated }\end{array}$ & 0.129 & 0.178 & 0.141 & 0.124 & 0.148 \\
\hline 2. & Mo & 0.0143 & 0.006 & 0.0039 & 0.0089 & 0.00749 \\
\hline 3. & $\begin{array}{c}\text { Ti }+\mathrm{Al}+ \\
\text { graphite }\end{array}$ & 0.0147 & 0.057 & 0.011 & 0.111 & 0.038 \\
\hline 4. & $\mathrm{Ti}+\mathrm{AlN}$ & 0.033 & 0.0031 & 0.01267 & 0.0283 & 0.0228 \\
\hline 5. & $\mathrm{Ti}+\mathrm{SiC}$ & 0.0168 & 0.0064 & 0.008 & 0.01 & 0.01 \\
\hline
\end{tabular}

Investigation of the coatings wear intensity has shown that both Mo and $\mathrm{Ti}+\mathrm{SiC}$ coatings can be used more efficiently in the friction and wear conditions described above than other coatings. Thus, the average wear intensity of the Mo coating was 3.04 times lower than that of the $\mathrm{Ti}+\mathrm{AlN}$ coating, 5.07 times lower than that of the $\mathrm{Ti}+\mathrm{Al}+$ graphite coating, and 20 times lower than that of the uncoated St. C45. It should be noted that the high wear resistance of the Mo coating is caused not only by its high microhardness (Table 2) and the lowest initial roughness (Table 3), but also by a high adhesion of molybdenum to the base material, forming intermetallic compounds $\left(\mathrm{Fe}_{2} \mathrm{Mo}_{3}\right.$, and $\mathrm{Fe}_{7} \mathrm{Mo}_{3}$ ) (Table 4). It is obvious that the $\mathrm{Ti}+\mathrm{SiC}$ coating microhardness is higher (Table 2) than that of the Mo coating. This is due to the fact that in this case a very hard phases $\left(\mathrm{SiO}_{2}, \mathrm{TiO}_{2}, \mathrm{TiC}\right)$ are formed on the surface (Table 4). However, the coating of $\mathrm{Ti}+\mathrm{SiC}$ had a wear intensity of 1.35 times higher than that of the Mo coating. It is supposed that this was because the $\mathrm{Ti}+\mathrm{SiC}$ coating had the highest initial roughness (Table 3).

Table 2. Initial microhardness of coatings obtained by ESA on St. C45.

\begin{tabular}{|c|c|c|c|c|}
\hline \multirow[b]{2}{*}{$\begin{array}{l}\text { Order } \\
\text { number }\end{array}$} & \multirow[b]{2}{*}{ Coating material } & \multicolumn{3}{|c|}{ Microhardness $H \mu$ determined at the load of $0.98 \mathrm{~N},(\mathrm{MPa})$} \\
\hline & & $\begin{array}{c}\text { Maximal } \\
\text { microhardness }\end{array}$ & $\begin{array}{c}\text { Average } \\
\text { microhardness }\end{array}$ & $\begin{array}{c}\text { Minimal } \\
\text { microhardness }\end{array}$ \\
\hline 1. & Mo & 10000 & 7920 & 4740 \\
\hline 2. & $\mathrm{Ti}+\mathrm{Al}+$ graphite & 7350 & 3990 & 2450 \\
\hline 3. & $\mathrm{Ti}+\mathrm{AlN}$ & 6800 & 3920 & 3100 \\
\hline 4. & $\mathrm{Ti}+\mathrm{SiC}$ & 13810 & 9650 & 6800 \\
\hline 5. & St. C45 uncoated & 2160 & - & - \\
\hline
\end{tabular}

Table 3. Variation of roughness parameters $\left(\mathrm{R}_{\mathrm{a}}, \mathrm{R}_{\mathrm{z}}\right)$ of electro-spark coatings before and after tribological testes.

\begin{tabular}{|c|c|c|c|c|c|}
\hline \multirow{2}{*}{$\begin{array}{c}\text { Order } \\
\text { number }\end{array}$} & \multirow{2}{*}{ Coating material } & \multicolumn{2}{|c|}{ Initial roughness, $(\mu \mathrm{m})$} & \multicolumn{2}{c|}{$\begin{array}{c}\text { Roughness of the coatings } \\
\text { after tribological tests, }(\mu \mathrm{m})\end{array}$} \\
\cline { 3 - 6 } & & $\mathrm{R}_{\mathrm{a}}$ & $\mathrm{R}_{\mathrm{z}}$ & $\mathrm{R}_{\mathrm{a}}$ & $\mathrm{R}_{\mathrm{z}}$ \\
\hline 1. & $\mathrm{Mo}$ & 2.9 & 15.46 & 2.7 & 13.94 \\
\hline 2. & $\mathrm{Ti}+\mathrm{Al}+$ graphite & 4.42 & 23.88 & 4.93 & 28.58 \\
\hline 3. & $\mathrm{Ti}+\mathrm{AlN}$ & 3.29 & 18.3 & 2.19 & 7.51 \\
\hline 4. & $\mathrm{Ti}+\mathrm{SiC}$ & 4.51 & 21.32 & 3.55 & 19.72 \\
\hline 5. & St. C45 uncoated & 0.63 & 2.96 & 4.03 & 20.54 \\
\hline
\end{tabular}


Table 4. Phases formed during electro-spark alloying of St. C45.

\begin{tabular}{|c|c|c|}
\hline $\mathrm{Nr} /$ or & Coatings composition & Phases composition \\
\hline 1. & $\mathrm{St} . \mathrm{C} 45$ & $\alpha-\mathrm{Fe}$ \\
\hline 2. & $\mathrm{Mo}$ & $\mathrm{Fe}_{2} \mathrm{Mo}_{3}, \mathrm{Fe}_{7} \mathrm{Mo}_{3}, \alpha-\mathrm{Fe}$ \\
\hline 3. & $\mathrm{Ti}, \mathrm{Al}$, graphite & $\mathrm{TiO}_{2}, \mathrm{FeO}, \mathrm{TiN}, \gamma-\mathrm{Fe}, \mathrm{Fe}{ }_{3} \mathrm{C}, \mathrm{AlFe}{ }_{3}, \alpha-\mathrm{Fe}$ \\
\hline 4. & $\mathrm{Ti}, \mathrm{AlN}$ & $\mathrm{TiO}_{2}, \mathrm{AlN}, \mathrm{TiN}, \mathrm{FeO}, \alpha-\mathrm{Fe}, \gamma-\mathrm{Fe}$ \\
\hline 5. & $\mathrm{Ti}, \mathrm{SiC}$ & $\mathrm{SiO}_{2}, \mathrm{TiO}_{2}, \mathrm{Fe}{ }_{3} \mathrm{C}, \mathrm{TiC}, \mathrm{FeO}, \alpha-\mathrm{Fe}, \gamma-\mathrm{Fe}$ \\
\hline
\end{tabular}

Figures 1 and 2 show the variations in the average values of the friction coefficients of coatings during the tribological tests in the first test period (run-in period) over a period of 30 minutes (2250 of cycles performed of friction pair) and in the fourth test period over a period of 75 minutes (5625 of cycles performed of friction pair). From Figure 1 it is clear that even at the beginning of the tests the average values of the coefficients of friction increase continuously and after 12 minutes they reach the value of 1.1 (for the $\mathrm{Ti}+\mathrm{SiC}$ coating). However, in the first 10 minutes, the average friction coefficients values increase in the $\mathrm{Ti}+\mathrm{Al}+$ graphite and the $\mathrm{Ti}+\mathrm{AlN}$ coatings. Even at the uncoated St. 45, to the tenth minute, the friction coefficient increases faster than of the coatings. It was observed that from the eighth minute the coefficients of friction of the $\mathrm{Ti}+\mathrm{AlN}$ coating are stabilized between 0.74-0.8 and those of the $\mathrm{Ti}+\mathrm{Al}+$ graphite coating - between $0.79-0.84$. It should be noted that the average values of friction coefficients of both the $\mathrm{Mo}$ and $\mathrm{Ti}+\mathrm{SiC}$ coatings after the twelfth minute up to the end of the test period were the highest - between 0.89-1.12. The contact surfaces of the coatings in the friction process were much smaller than the nominal surfaces. This is because the peaks of the roughness of the coatings are very tough and in the friction process they are difficult to wear, which leads to an increase of pressure and of the friction coefficient. However, from Table 1 and Figure 1 a clear correlation can be noticed: the higher the microhardness of the coating (including the uncoated St.C45), the higher the friction coefficient (after stabilization over 8-12 minutes) and vice versa.

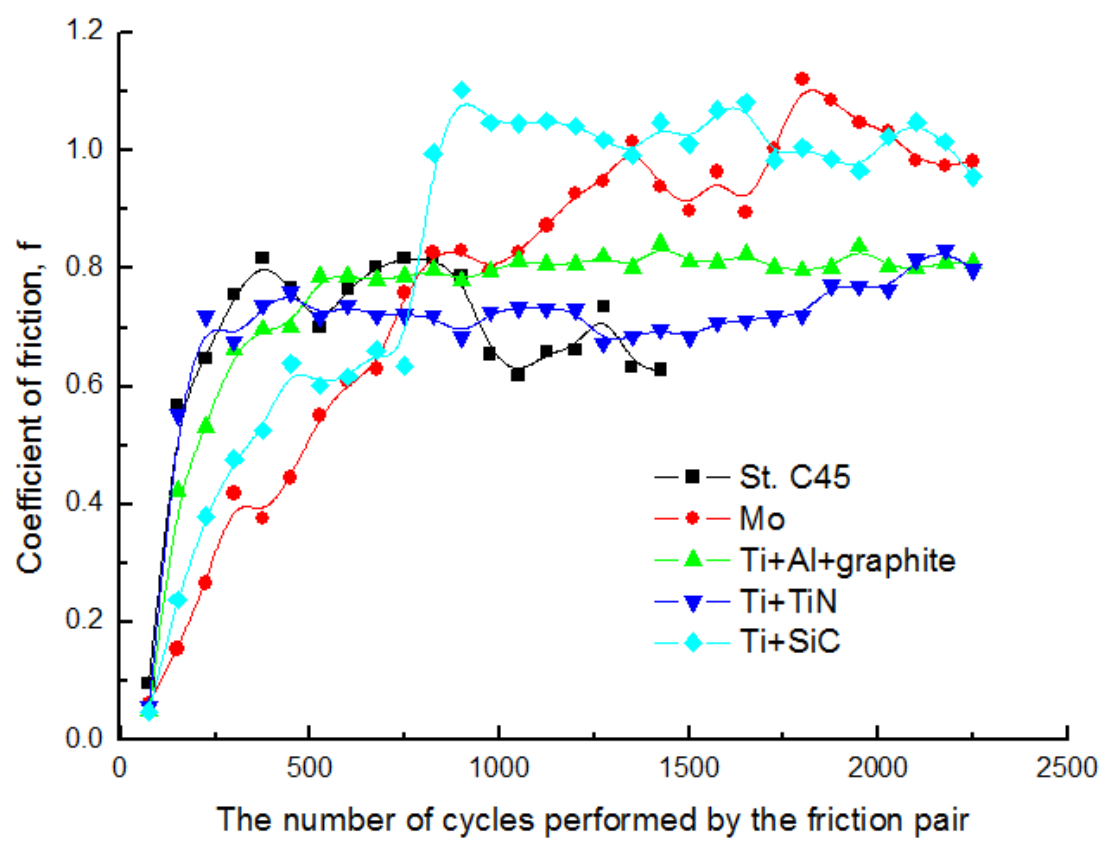

Fig. 1. Variations in average values of friction coefficients of coatings during tribological tests in the first test period. 


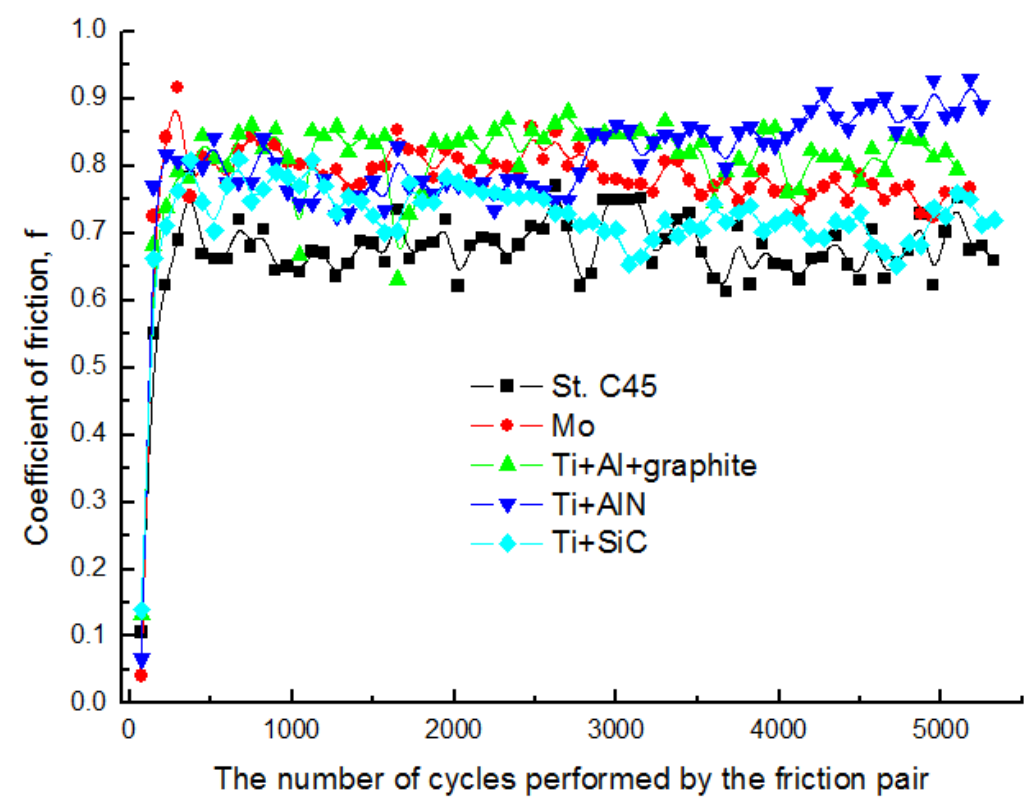

Fig. 2. Variations in average values of friction coefficients of coatings during tribological tests in the fourth test period.

As is clear from Figure 2, the coefficients of friction of all coatings varied over the entire test period. The value of the friction coefficients had a tendency to increase in the direction of St. C45 $\rightarrow \mathrm{Ti}$ $+\mathrm{SiC} \rightarrow \mathrm{Mo} \rightarrow \mathrm{Ti}+\mathrm{Al}+$ graphite $\rightarrow \mathrm{Ti}+\mathrm{AlN}$. It should be noted that if in the first period of tribological testing of the coatings (Figure 1) the highest friction coefficients were those of both $\mathrm{Ti}+\mathrm{SiC}$ and Mo coatings, while during the fourth period those coatings (Figure 2) had the lowest friction coefficients of over a long time. This proves that these coatings, due to their natural properties, have the highest tribological properties, manifested by a lower adhesion of these coatings to U8 steel, which was used as a counterbody.
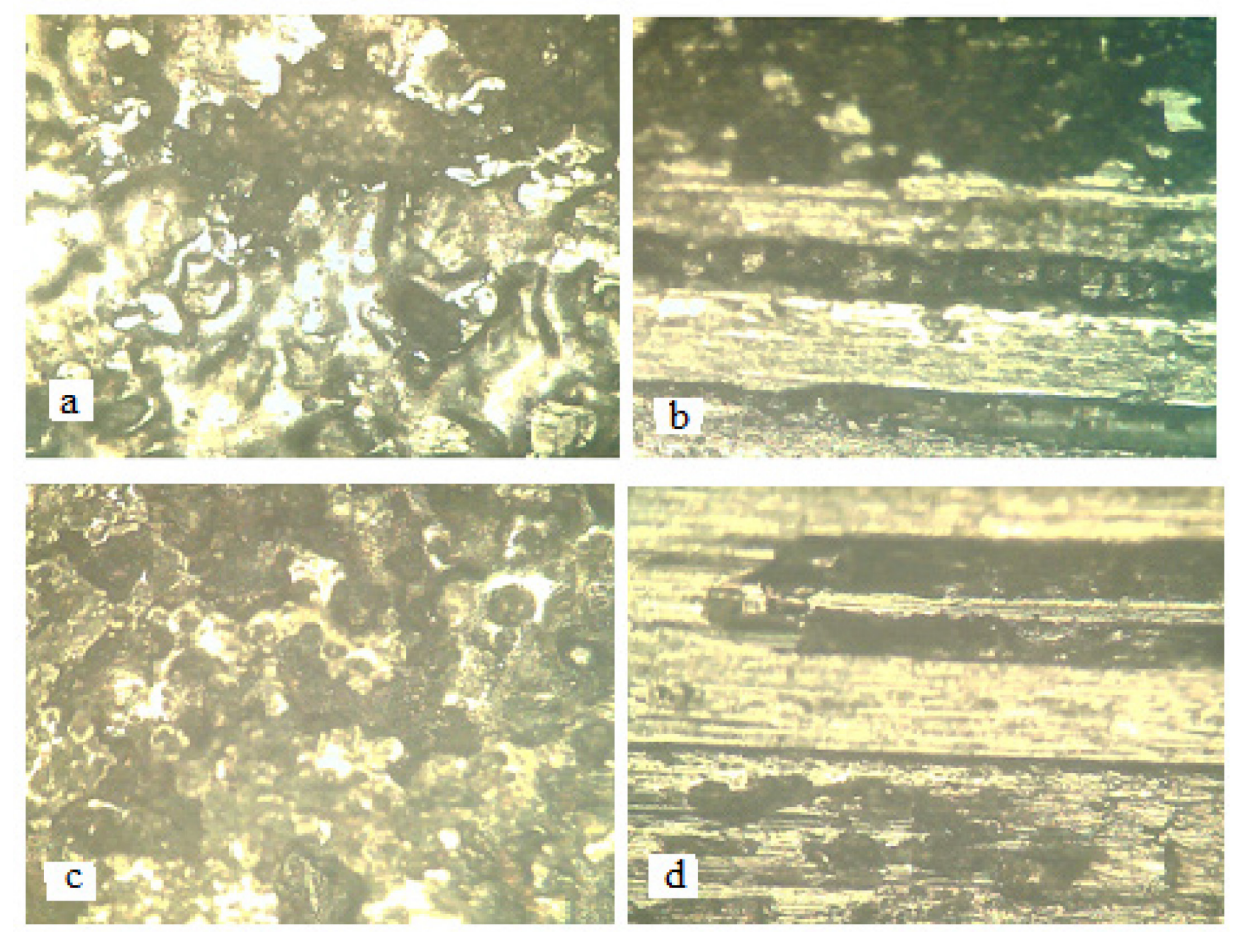

Fig. 3. Micrographs of wear surfaces of coatings after 225 minutes (16875 cycles) of tribological tests: a - Mo; b - Ti + Al + graphite; c - Ti + SiC; d - uncoated St. C45; x 125. 
Figure 3 shows the optical micrographs of the friction surfaces of coated (a, b, c) and uncoated St. 45 (d) after the entire tribological test period. These microphotographs clearly demonstrate that the Mo coating (Figure 3a) had the least change in the friction and wear processed followed by the Ti $+\mathrm{SiC}$ coating (Figure $3 \mathrm{c}$ ). It should be noted that the friction surface of the coating $\mathrm{Ti}+\mathrm{Al}+$ graphite (Figure $3 \mathrm{~b}$ ) has undergone the greatest changes. The friction surface shows traces of wear of 48-60 $\mu \mathrm{m}$, formed along the sample in the direction of the sliding motion, showing that the wear particles of the coating contributed to the abrasive wear of the coating. Therefore, the most destroyed friction surface very clearly correlates with the highest average wear intensity of a coating over the entire test period. Studying the friction surface of the uncovered St.C45 sample (Figure 3d), it can be said that this surface was destroyed by several wear mechanisms, namely abrasive wear and additional wear.

\section{Conclusions}

From all the above-mentioned results, the following conclusions can be made:

1. It was determined that under friction without lubrication and at a specific pressure of $2 \mathrm{MPa}$, the lowest average wear intensity had the Mo coating - 20 times lower than that of the uncoated St. C45.

2. It can be recommende to use (for the conditions discussed above) primarily the Mo coating and then the $\mathrm{Ti}+\mathrm{SiC}$ coating (which had an average wear intensity of 14.76 lower than the uncoated St. C45).

3. A clear correlation was determined in the first test period: the higher the microhardness of the coating (including the uncoated St. C45), the higher the friction coefficient (after stabilization over 8-12 minutes) and vice versa.

4. Both the $\mathrm{Ti}+\mathrm{Al}+$ graphite and $\mathrm{Ti}+\mathrm{AlN}$ coatings have reduced the wear of St. C45, as 3.9 and 6.5 , respectively. Therefore, these coatings have to be obtained at other electro-spark alloying regimes in order to obtain higher tribotechnical propertes coatings and test them again.

\section{Acknowledgments}

The authors acknowledge funding from the H2020-MSCA- RISE project SMARTELECTRODES (Grant Nr 778357).

\section{References}

[1] A.E. Gitlevich, V.V. Mikhailov, N.Ya. Parkanskii, B.M. Revutsky, Elektroiskrovoe legirovanie metallicheskikh poverkhnostei, Shtiintsa, Kishinev, 1985. (in Russian).

[2] V. I. Agafii, V. A. Yurchenko, V. I. Yurchenko, V. M. Fomichev, V. I. Petrenko, A. I. Dikusar, Wear resistance of coatings manufactured by electric spark plating with Al-Sn electrodes, Surface Engineering and Applied Electrochemistry. 2011, 47(6), 12-16.

[3] V. I. Agafii, V. I. Petrenko, V. M. Fomichev, V. I. Yurchenko, E. V. Yurchenko, A. I. Dicusar, Electrospark alloying for deposition on aluminum surface of Al-Sn coatings and their wear resistance under dry friction, Surface Engineering and Applied Electrochemistry. 2013, 49(3), 1-8.

[4] J. Padgurskas, V. Agafii, V. Mikhailov, R. Rukuiza, and R. Kreivaitis, Tribological Properties of Combined Molybdenum Coatings Formed by Electric-Spark Alloying on Stainless Steel, ISSN 10683666, Journal of Friction and Wear. 2016, Vol. 37, No. 5, 448-453.

[5] J. Padgurscas, R. Kreivaitis, R. Rukuiza, V. Mihailov, V. Agafii, R. Kriukiene, A. Baltusnikas, Tribological properties of coatings obtained by electro-spark alloying C45 steel surfaces, Surface and Coatings Technology. 2017, Vol. 311, 90-97 (15 February). 